\title{
地震により曲げ破壊した鉄筋コンクリート橋脚 に対する緊急復旧エ法の提案
}

\author{
堺 淳一1・運上 茂樹2 \\ 1正会員 博 (工) (独) 土木研究所構造物メンテナンス研究センター橋梁構造研究グループ \\ 主任研究員（テ305-8516 茨城県つくば市南原1-6） \\ E-mail: sakai55@pwri.go.jp \\ 2正会員 工博 国土交通省国土技術政策総合研究所危機管理技術研究センター地震災害研究官 \\ ( テ305-0804 つくば市旭 1 番地) \\ E-mail: unjoh-s92ta@nilim.go.jp
}

\begin{abstract}
被災発見後に速やかに被災診断を行い，余震の影響を適切に考慮して残存而震性能を評価する手法とと もに，即効性のある復旧工法を用いて迅速かつ合理的に機能回復を図るための忘急復旧技術の開発が必要 とされている．本研究では，柱基部で曲げ破壊する鉄筋コンクリート橋脚を対象として，被災後の余震の 影響を調べるとともに，迅速な応急復旧工法に対する要求性能を整理し，即効性のある応急復旧工法を提 案し, その効果を評価するために振動台加震実験を行った. 即効性のある復旧工法としては, 速乾性の材 料を用いた炭素繊維シートによる修復と機械式に定着された繊維バンドによる修復を提案し，これらの工 法により，被災前の状態に比べて剛性は低下するが，曲げ耐力，変形性能ともに損傷前と同程度またはそ れ以上の性能が確保できることを示した。
\end{abstract}

Key Words : reinforced concrete bridge column,earthquake damage, seismic performance, aftershock rapid repair method, shake table test

\section{1. はじめに}

大規模な地震が発生した場合，道路橋などのライフラ イン構造物の被災状況の把握とそれに基づく災害時道路 ネットワークの確保は，地震直後の救急救命活動，被災 者の避難，救援物資輸送等の震後対応において極めて重 要である，道路橋が被災した場合には，まずはその被災 を発見するとともに，被災の程度を把握することが重要 であり, その後, 必要に応じて道路橋の機能を応急的に 確保するために修復が行われる.

地震後の被災調查・被災診断，応急復旧や本復旧工法 の選定に関しては，兵庫県南部地震の経験を含む過去の 震災経験を反映した道路震災対策便覧（震災復旧編） ${ }^{1)}$ が活用されている。一方，2004 年 10 月に発生した新潟 県中越地震では，橋梁構造物の被災発見後，被災診断， 復旧工法の選定，復旧工事の実施に約 1 週間を要し，こ の間通行止めを余儀なくされるという事例が見られ，機 能回復に要する時間を短縮することの重要性が再認識さ れた ${ }^{2)}$. また, 本震発生後 1 週間程度の間に規模の大き な余震が頻発したため，応急復旧作業を中断せざるを得 ない状況がたびたび発生した。このため，速やかに構造
物の被災を検知する手法および被災発見後に構造物の余 震に対する安全性を適切に考慮して速やかに被災診断を 行う手法の構築とともに，即効性のある復旧工法を用い て迅速かつ合理的に橋梁構造物の機能回復を図るための 応急復旧技術の開発が必要とされている.

即効性のある応急復旧工法については，Yarandi と Saatciglu が横方向のプレストレスによる工法を提案して

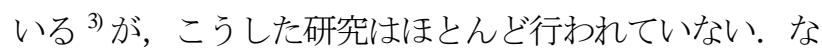
お，三田村らは応急復旧工法ではなく而震補強工法とし てであるが，迅速な施工を目的としてアラミドロープに よる巻き立て工法を提案している ${ }^{4}$.

著者らは，こうした震後の対応を支援する技術を開発 するための研究を行っており, 速やかに構造物の被災を 検知する手法については, 橋梁地震被災度判定システム を開発し，すでに文献5)等で報告している。一方，被災 発見後に必要とされる技術に関しては，柱基部で曲げ破 壊する鉄筋コンクリート（RC）橋脚を対象として，被 災後の余震の影響を調べるとともに，迅速な応急復旧工 法に対する要求性能を整理し，即効性のある工法を提案 し，その効果を評価するために振動台加震実験を行った. 本文ではその結果を報告する. 
表-1 実験対象とした橋脚模型

\begin{tabular}{|c|c|c|c|}
\hline & 模型A & 模型B & 模型C \\
\hline セセットアップ & 11本柱形式 & 桁+支承形式 & 桁+支承形式 \\
\hline 断面 & $\phi 600 \mathrm{~mm}$ & $\phi 600 \mathrm{~mm}$ & $\phi 600 \mathrm{~mm}$ \\
\hline 慣性力載荷点高さ（括弧内はTR方向） & $3 \mathrm{~m} \quad(3 \mathrm{~m})$ & $2.5 \mathrm{~m} \quad(3.65 \mathrm{~m})$ & $2.675 \mathrm{~m} \quad(3.811 \mathrm{~m})$ \\
\hline 上部構造慣性質量（括弧内はTR方向） & 27 ton (27 ton) & 37.8 ton (26.6 ton) & 36.4 ton (25.5 ton) \\
\hline 柱基部軸応力 & $0.99 \mathrm{~N} / \mathrm{mm}^{2}$ & $1.04 \mathrm{~N} / \mathrm{mm}^{2}$ & $1.01 \mathrm{~N} / \mathrm{mm}^{2}$ \\
\hline 軸方向鉄筋比（鉄筋径：本数） & $1.01 \%$ (D10 : 40本) & $2.02 \% \quad(\mathrm{D} 10: 80$ 本 $)$ & $2.42 \%$ (D10 : 96本) \\
\hline 帯鉄筋比（鉄筋径：間隔） & $0.33 \%(\mathrm{D} 6: 75 \mathrm{~mm})$ & $0.21 \%(\mathrm{D} 3: 50 \mathrm{~mm} *)$ & $0.49 \%(\mathrm{D} 6: 100 \mathrm{~mm})$ \\
\hline 曲げ耐力（LG方向の場合） & $95 \mathrm{kN}$ & $184 \mathrm{kN}$ & $215 \mathrm{kN}$ \\
\hline 初期固有周期（括弧内はTR方向） & 0.28 秒 $(0.27$ 秒 $)$ & 0.25 秒 $(0.38$ 秒 $)$ & 0.28 秒 $(0.39$ 秒 $)$ \\
\hline 相似率 & 4 & 3 & 4 \\
\hline 損傷させる実験の入力地震動の振幅 & $10 \%, 20 \%, 30 \%, 50 \%, 60 \%$ & $10 \%, 80 \%$ & $10 \%, 50 \%, 80 \%, 120 \%$ \\
\hline 修復効果確認実験の入力地震動の振幅 & $10 \%, 50 \%, 60 \%$ & $10 \%, 55 \%, 80 \%$ & $10 \%, 80 \%, 120 \%$ \\
\hline
\end{tabular}

*) 模型Bの帯鉄筋は, 柱基部において外側帯鉄筋が50 mm間隔, 中側, 内側帯鉄筋は100 mm間隔である。
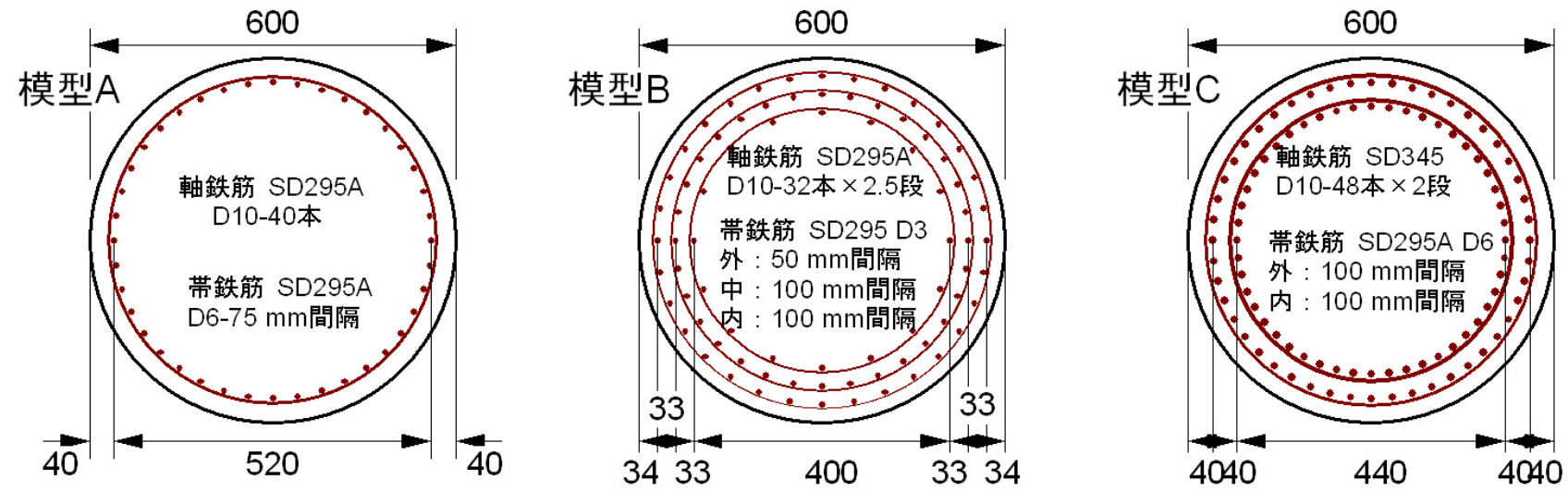

図-1＼cjkstart実験対象とした橋脚模型の柱基部の断面

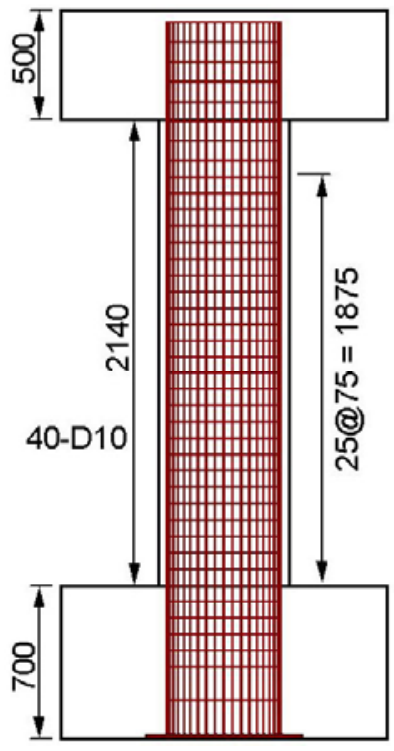

(a) 模型A

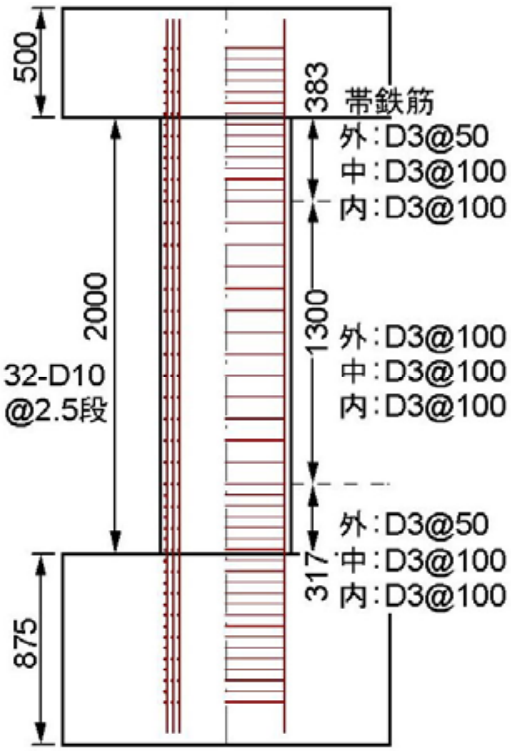

(b) 模型 $\mathrm{B}$

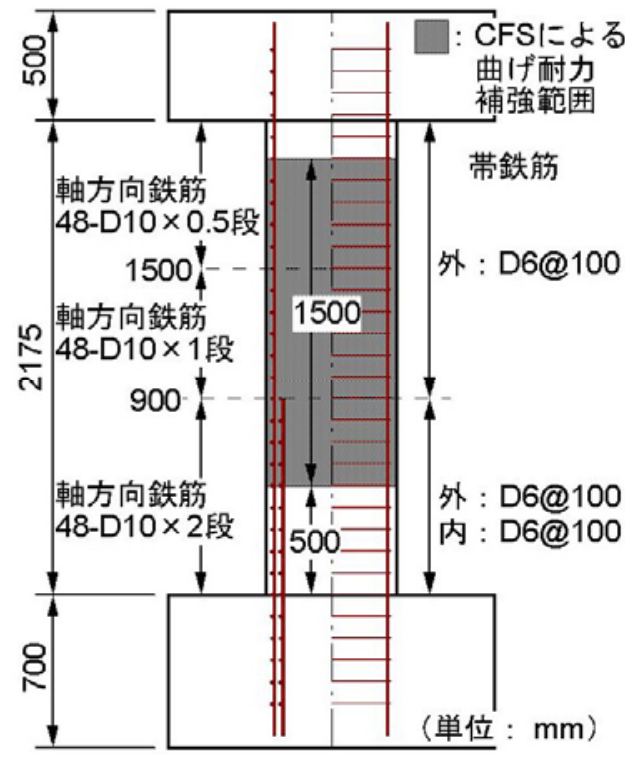

(c) 模型C

図-2 実験対象とした橋脚模型の柱部の配筋

2. 被災したR C橋脚の余震に対する応答特性

\section{(1) 実験模型}

地震により損傷を受けた RC 橋脚に余震によってどの 程度の地震応答が生じるか，損傷が進展するかを調べる
ために，円形断面を有する鉄筋コンクリート橋脚模型を 対象に振動台加震実験を行った．対象は柱基部で曲げ破 壊する RC 橋脚とした. 本文ではこれを模型 A と呼ぶ.

表-1 に実験模型の諸元を示す. 図-1 に実験模型の断 面を，図-2 に模型の柱部の配笳を，図-3に実験模型の 


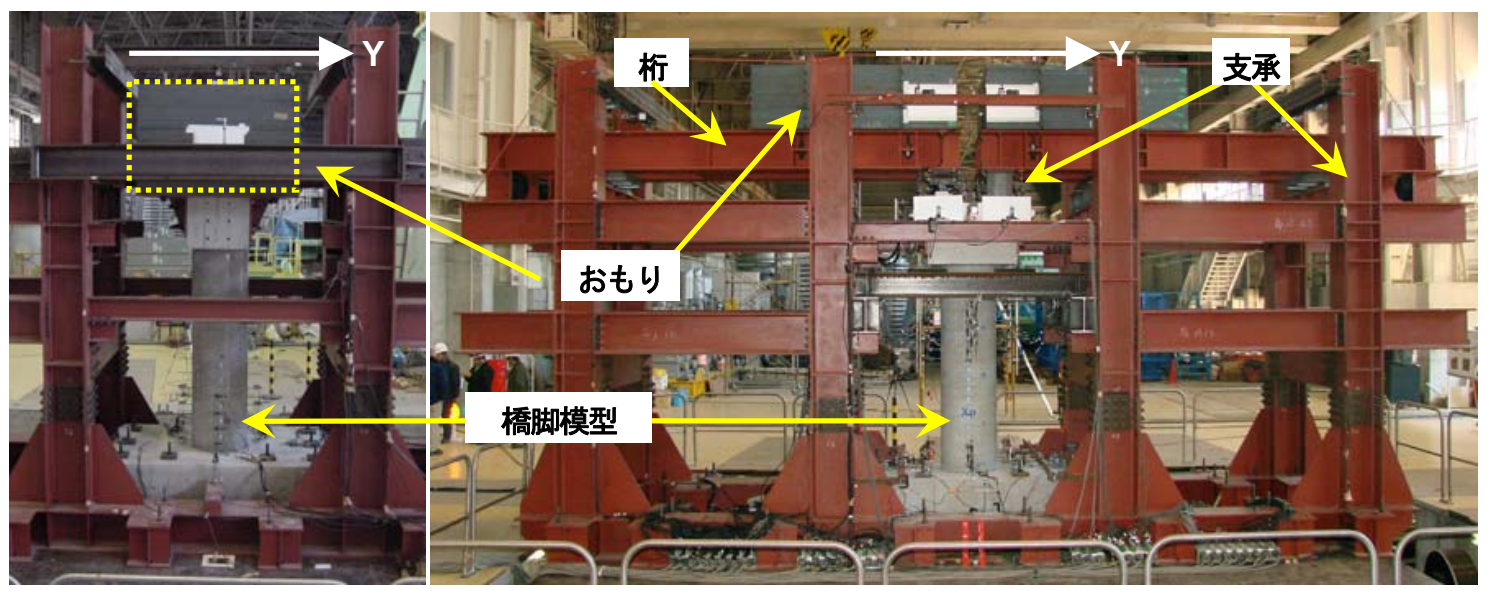

(a)1本柱形式

(b) 桁十支承形式

図-3 実験セットアップ (写真手前方向がX方向の正の向き)

表-2 材料特性

\begin{tabular}{|l|c|c|c|}
\hline & 模型A & 模型B & 模型C \\
\hline \hline コンクリートの弾性係数 $\left(\mathrm{kN} / \mathrm{mm}^{2}\right)$ & 28.5 & 28.8 & 26.7 \\
\hline コンクリートの圧縮強度 $\left(\mathrm{N} / \mathrm{mm}^{2}\right)$ & 23.0 & 27.9 & 31.9 \\
\hline 軸方向鉄筋の弾性係数 $\left(\mathrm{kN} / \mathrm{mm}^{2}\right)$ & 182.8 & 178.3 & 186.5 \\
\hline 軸方向鉄筋の降伏強度 $\left(\mathrm{N} / \mathrm{mm}^{2}\right)$ & 391.5 & 351.4 & 394.0 \\
\hline 帯鉄筋の弾性係数 $\left(\mathrm{kN} / \mathrm{mm}^{2}\right)$ & 182.9 & 212.9 & 185.2 \\
\hline 帯鉄筋の降伏強度 $\left(\mathrm{N} / \mathrm{mm}^{2}\right)$ & 380.4 & 280.4 & 327.0 \\
\hline
\end{tabular}

セットアップ状況をそれぞれ示す.ここには後述する模 型 $\mathrm{B}$ ，模型 Cについてもあわせて示している.

模型 A は，我が国で建設される一般的な都市高架橋 の RC 橋脚の約 4 分の 1 のサイズとし, 既往の地震によ つて被害が比較的多く生じている昭和 55 年道路橋示方 書より古い基準に準拠した橋脚を想定した．柱の断面は， 直径 $0.6 \mathrm{~m}$ の円形とした．橋の上部構造による慣性力お よび軸力を模擬するために，RC 橋脚模型の頂部には鋼 板を載せた．慣性質量は 27 ton，柱基部における圧縮軸 力は $280 \mathrm{kN}$ となる. これを軸応力として表すと 0.99 $\mathrm{N} / \mathrm{mm}^{2}$ である. 模型高さは，せん断支間比が 5 となるよ うに設定した。 これより，慣性力作用位置（上部マスと 上部スラブの重心位置) は柱基部から $3 \mathrm{~m}$ の位置となる. 本実験では，図-3 に示すように $\mathrm{X}$ 方向，Y 方向を定義 した.

橋脚模型には，軸方向鉄筋として直径10 mmの異形棒 鋼（D10）を40本，帯鉄筋として直径6 $\mathrm{mm}$ の異形棒鋼 （D6）を75 mm間隔で配置した. 軸方向鉄筋比および横

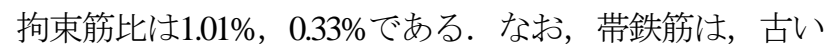
基準に準拠した橋脚を想定したため，フックを用いず, 重ね継ぎ手によりコンクリートに定着した。定着長は, $170 \mathrm{~mm}$ とた.

表-2 にコンクリートおよび鉄筋の材料特性を示す. ここには後述する 2 つ模型の材料試験結果もあわせて 示している．模型 $\mathrm{A}$ に用いた軸方向鉄筋，帯鉄筋の降 伏強度はそれぞれ $392 \mathrm{~N} / \mathrm{mm}^{2} ， 380 \mathrm{~N} / \mathrm{mm}^{2}$ である. コンク
リートの設計基準強度は $24 \mathrm{~N} / \mathrm{mm}^{2}$ であり，実験日（材 齢 20 日）の実測強度は $23 \mathrm{~N} / \mathrm{mm}^{2}$ であった。

\section{(2) 入力地震動}

実験は，土木研究所が所有する三次元大型振動台を用 いて行った. 加震は水平 2 方向十上下方向の三次元加震 とし, 入力地震動としては, 兵庫県南部地震の JR 鷹取 駅の記録 6を用いることとした. X方向に EW 成分を, $\mathrm{Y}$ 方向に NS 成分を, Z 方向に UD 成分を入力すること とした.

実験模型は実橋脚の約 4分の 1 のサイズを想定してい るため，相似則 ${ }^{7} よ り$ 時間軸を 50\%に圧縮した。加震振 幅は，様々な塑性率における応答特性を調べるために,

表-3 に示すように振幅を 10\%，20\%，30\%，50\%，60\% と徐々に増加させることとし，本震を想定した加震のあ とに余震を想定した本震と同強度の入力地震動を作用さ せた。 なお，表-3 には実験模型の固有周期，応答と損 傷の進展も示しているが，これに関しては後述する.

各加震の前には各方向に60秒間のホワイトノイズを入 力し，橋脚模型の固有周期特性を調べた.

図-4は，振動台上で観測された加速度（入力加速度） による応答スペクトルを，振幅が $60 \%$ の加震を例にJR鷹 取駅の記録 (入力波) と比較した結果である.ここには 後述する提案工法による復旧後の加震実験における同レ ベルの加震の加速度による結果も示している. これによ れば，入力波とは異なる周期帯もあるが，同強度の加震 においては，振動台上で観測された加速度による加速度 応答スペクトルは互いにほぼ一致しており，振動台はこ れらの加震による結果を比較するに十分な再現性を有し ていた.

\section{(3) 破壊性状と応答特性}

表-3 は，各加震における慣性力作用位置の最大応答 変位と損傷をまとめた結果である，応答変位が大きくな 
表-3 各加震における応答と損傷

\begin{tabular}{|c|c|c|c|c|c|c|c|}
\hline & \multicolumn{2}{|c|}{ 加震前の周期 (秒) } & \multicolumn{3}{|c|}{ 最大振幅 $(\mathrm{mm})$} & \multirow{2}{*}{ 損傷状態 } \\
\hline & & X方向 & Y方向 & X方向 & Y方向 & 距離 & \\
\hline 10\%加震 & 弾性 & 0.28 & 0.27 & 3 & 4 & 4 & 無損傷 \\
\hline \multirow{2}{*}{$20 \%$ 加震 } & 本震 & 0.30 & 0.30 & 8 & 14 & 14 & 曲げひびわれ \\
\hline & 余震 & 0.32 & 0.31 & 14 & 16 & 20 & 曲げひびわれの進展 \\
\hline \multirow{2}{*}{$30 \%$ 加震 } & 本震 & 0.34 & 0.33 & 29 & 42 & 47 & 残留ひびわれを確認 \\
\hline & 余震 & 0.56 & 0.59 & 36 & 55 & 61 & 縦ひびわれ, コンクリートの浮き \\
\hline \multirow{2}{*}{$50 \%$ 加震 } & 本震 & 0.59 & 0.60 & 53 & 86 & 93 & 基部でコンクリートの軽微な剥落 \\
\hline & 余震 & 0.67 & 0.65 & 50 & 82 & 87 & かぶりコンクリートの剥落 \\
\hline \multirow{2}{*}{$60 \%$ 加震 } & 本震 & 0.62 & 0.67 & 60 & 101 & 108 & かぶりコンクリートの剥落, 軸方向鉄筋のはらみだし \\
\hline & 余震 & 0.67 & 0.85 & 60 & 114 & 121 & 上記の損傷が全周に広がる \\
\hline
\end{tabular}
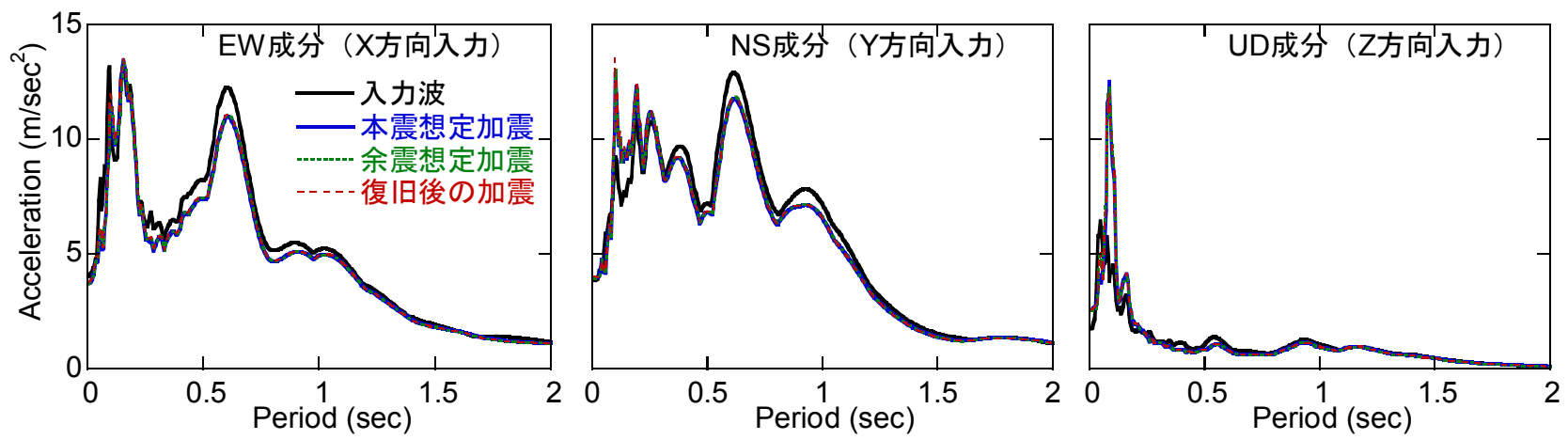

図-4 入力地震動の加速度応答スペクトル（模型 $\mathrm{A}$ の $60 \%$ 加震の場合，減衰定数=5\%）

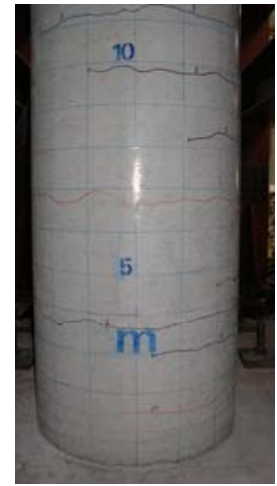

(a) 本震加震後

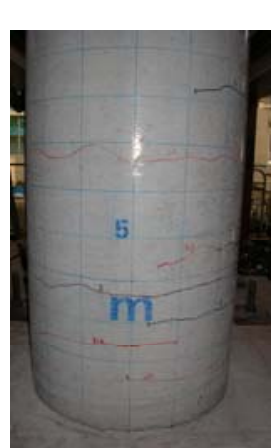

(b) 余震加震後 (1) $30 \%$ 加震後

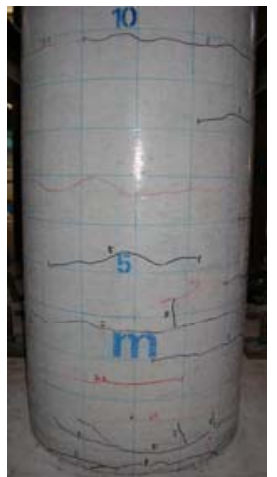

(a) 本震加震後

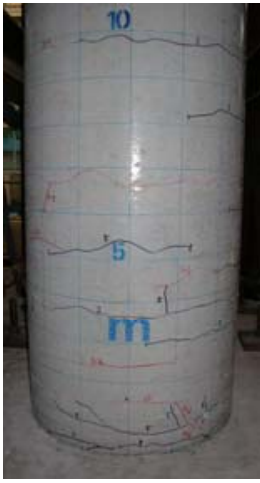

(b) 余震加震後

(2) $50 \%$ 加震後

図-5 損傷の進展

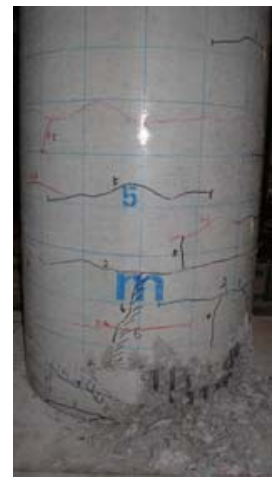

(a) 本震加震後 (3) $60 \%$ 加震後

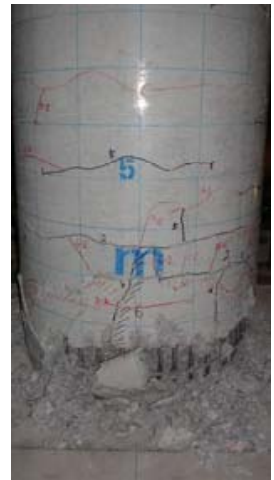

(b) 余震加震後
ると残留変位が生じたが，ここでは最大振幅を比較する ために, 前回の加震の残留変位值からの振幅を最大応答 として示している. また, 三次元加震のため, 表には次 式により求めた原点からの距離も示している.

$$
d_{t}=\sqrt{d_{X \cdot t}^{2}+d_{Y \cdot t}^{2}}
$$

ここで， $d_{X \cdot t}, d_{Y \cdot t}$ はそれぞれ時刻 $t$ における $X$ およ び Y 方向の応答変位である. また，表-3 には，ホワイ トノイズテストの結果から求めた橋脚模型の固有周期の 変化も示している.

図-5 には，損傷の進展の例として，30\%加震，50\%加
震，60\%加震の後の模型の損傷状況を示している. 図-6 は 50\%加震, $60 \%$ 加震を例に水平力〜水平変位の履歴を 示した結果である.ここには，本震を想定した加震と余 震を想定した加震を比較した結果を示す.

10\%加震後には目視による観察ではひびわれ等は確認 されなかった.この後，20\%加震において曲げひび割れ， 50\%加震において基部のコンクリートに軽微な剥落, 60\%加震においてかぶりコンクリートの剥落，軸方向鉄 筋のはらみ出しが生じた。帯鉄筋のゆるみ・はずれは観 察されなかった。コアコンクリートの圧壊も一部確認さ れた. 初期には 0.27 秒程度であった固有周期は $60 \%$ 加 震後には 0.67 秒 $~ 0.85$ 秒まで増加した.

本震の後に，余震として本震と同強度の地震力が作用 


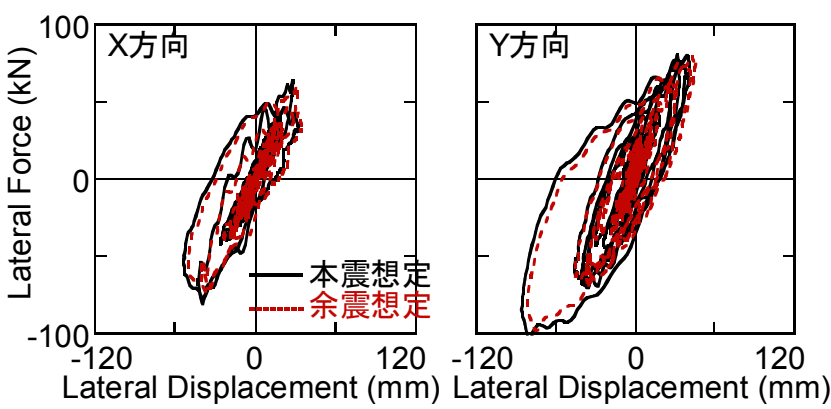

(a) 振幅 $50 \%$ 加震

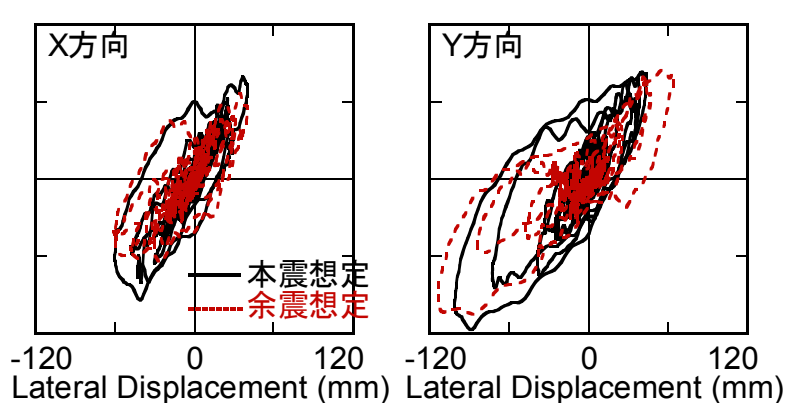

(b) 振幅 $60 \%$ 加震

図-6 本震および本震と同強度の余震に対する模型 $\mathrm{A}$ の応答

すると, 応答変位は増加したり, 損傷が進展する場合も あるが，本研究では，かぶりコンクリートが剥落し，軸 方向鉄筋がはらみ出すという道路橋示方書における終局 変位に相当する段階の損傷レベルが生じた後にも，本震 規模の余震によって, 橋脚の耐震性能が低下寸るレベル の損傷の進展は観察されなかった。これは，本実験では 帯鉄筋のゆるみやはずれがなく，また，コアコンクリー 卜の圧壊も限定的であったためと考えられる．以上より， 基部で曲け破壊するタイプの RC 橋脚は，軸方向鉄筋が 破断する前の段階では本震規模の余震に対しても耐震性 能が大きく低下しないと考えられる.

\section{R C 橋脚の即効性のある応急復旧工法}

\section{(1) 即効性のある応急復旧工法の要求性能}

本研究で提案する応急復旧工法に対する要求性能は以 下の通りとした.

a) 余震に対する応急的な安全性の確保のため, 脆性的 な破壊を防止すること

b)品質管理が容易であること

c) 1 日程度で復旧作業が完了すること

d) 重機等による施工を必要としないこと

e) 資材は長期間, 備蓄可能なこと

上記の a)，b)は耐震性能の観点からの要求性能である. a)の脆性的な破壊を防止するという性能は，せん断破壞 を防止すること，あるいは変形性能を確保すること，も しくはその両者により満足される，また，b)は復旧後の 性能（品質）を確保するという観点から重要である。こ れについては, 作業に特殊な技術を要しないことも要求 される，c), d)は施工に関する要求性能であり, 応急復 旧の作業において迅速，簡便であることを要求するもの である. e)は平成 16 年の新潟県中越地震の例では修復 資材の調達にもある程度の時間を要したという報告があ

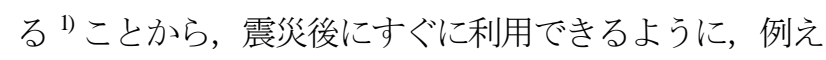
ば橋を管理する事務所や「道の駅」等に資材を長期間備 蓄できるようにするための要求性能である.
本研究では, 特にc)の要求性能に着目して, 以下に示 す速乾性材料を用いた炭素繊維シート巻立て工法と機械 式定着による繊維バンド巻立て工法を提案した.

\section{（2）速乾性材料を用いた炭素繊維シート巻立て工法}

本工法は，従来型の炭素䋊維シート（CFS）巻立て工 法において，使用する材料に速乾性のメチルメタクリレ 一ト (MMA）樹脂 ${ }^{8)}$ を用いて復旧に要する時間を 1 日 以内とする工法である. 一般的な工程は以下に示寸とお りであり, 修復された断面の概念図および修復作業の様 子を図-7に示寸.

1. 損傷したコンクリートの除去, 修復部の清掃

2. 下地処理剤（プライマー）の塗布

3. モルタル等による断面修復

4. 不陸修正材 (パテ) 等による表面不陸の修正

5. 樹脂系の含浸接着剤によるシートの貼り付け (複数層のシートを巻く場合にはこれをくり返す)

6. 而候性のための表面仕上げ

一般には工程 2 ～5では，材料が乾くまでそれぞれ 1 日程度の養生期間が必要であるため, 作業完了まで 3〜 5 日程度を要するが, 提案工法では, 断面修復材, 下地 処理剤（プライマー），不陸修正材（パテ）, 含浸接着 剂に MMA 樹脂系材料を用いることにより，各工程の養 生時間を 1 時間程度にして, 全体工程を 1 日程度におさ めることとした.

本工法では，CFS を接着剤により橋脚身体に貼り付け るため, 十分なせん断補強効果が期待できる. また, 曲 げ破壊するタイプにも CFS による横拘束効果による変 形性能向上が期待できる. ただし，後述の実験により柱 の変形量が大きくなると CFS が破断するため, これら の効果を大きくは期待できないことが明らかになった.

断面修復には樹脂モルタルを用いる。 これは, 練り混 ぜに用いられる水が CFS の接着性に悪影響を及ぼすこ とから CFS を巻立てる場合には一般にはセメント系の モルタルは適さないためである. 樹脂モルタルは, 粘性 


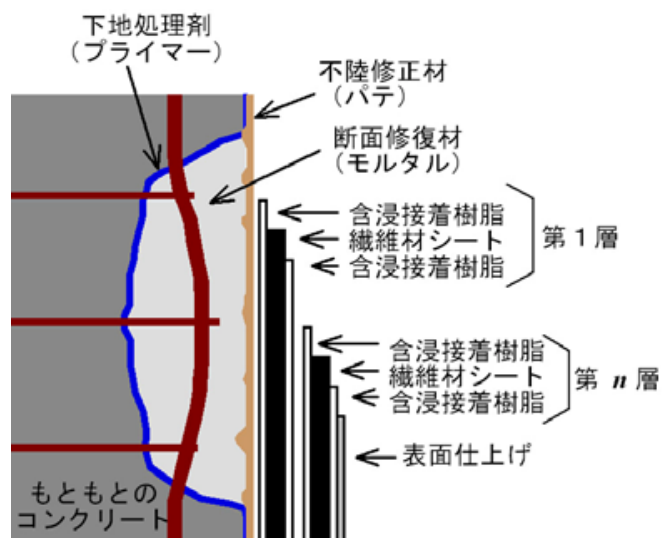

(a) 応急復旧後の断面
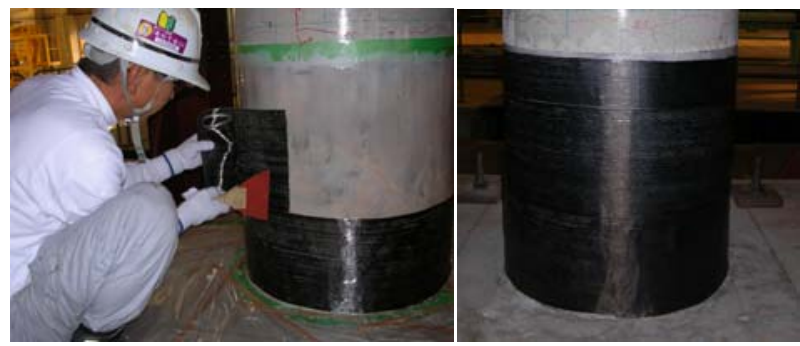

(b) 復旧作業の様子と復旧後の柱基部

図-7速乾性材料を用いた CFS 巻立て工法

が高く，手でこねながら損傷断面に塗り込めることから， その充填性はそのたびの施工に依存寸るため，品質管理 が難しいという欠点がある。 これより，後述のように材 料試験では弾性係数, 圧縮強度に大きなばらつきが生じ た.

本工法の作業は, 一般の CFS 巻立て工法と変わらな いため，特殊な技術は要さない，また，CFS は軽いため, 施工には重機を要さない点も要求性能を満足する．ただ し，一般には樹脂系の材料は品質保証期間が 6 ケ月程度 とされており，長期の備蓄には不向きである.

\section{(3) 機械式定着による䋊維バンド巻立て工法}

本工法は，断面修復は超速硬性無収縮モルタルにより 行い，断面修復後に繊維バンドを機械式定着によって巻 立てる工法である．本文ではこれを機械式定着工法と呼 ぶ.一般的な工程は以下に示すとおりであり，修復され た断面の概要を図-8に示寸.

1．損傷したコンクリートの除去，修復部の清掃

2. 下地処理剂（プライマー）の塗布

3. モルタル等による断面修復

4. 機械式定着による繊維バンドの巻立て

本工法では，繊維バンドを橋脚躯体に接着しないため, せん断耐力補強の観点からは CFS 巻立て工法よりも劣 ると考えられる．曲け破壊する場合には，綫維バンドに よる横拘束効果による変形性能の向上が期待できる.

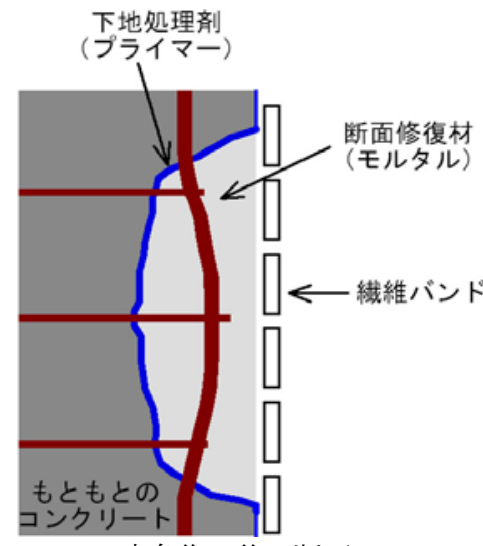

(a) 応急復旧後の断面

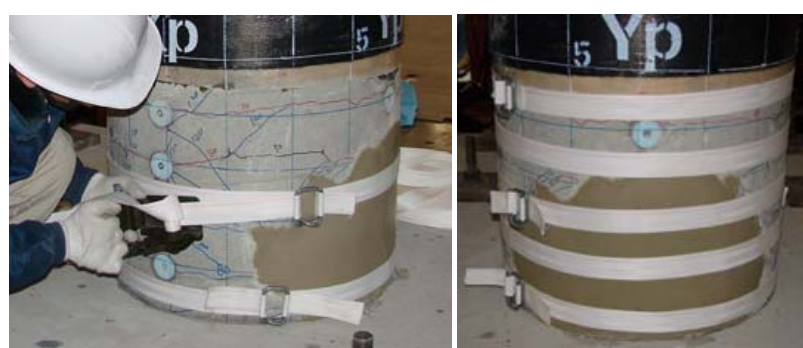

(b)復旧作業の様子と復旧後の柱基部

図-8 機械式定着による䋊維バンド巻立て工法

断面修復に用いるのはセメント系のモルタルであるた め, 樹脂系のモルタルに比べて施工性がよく, 品質管理 も比較的容易である. なお，緊急の復旧工法の観点から は重要度は高くないが，MMA 樹脂モルタルよりも廉価 な点も利点として挙げられる.

繊維バンドを巻立てる作業は，簡単な作業であり特殊 な技術は要さない。また，䋊維バンドは，CFS と同様に 軽いため, 施工には重機を要さない点も要求性能を満足 する.さらに，本工法で用いた材料は，用いる繊維材に よっては紫外線による劣化等があるため, 備蓄には紫外 線を防ぐ等の対策が必要な場合もあるが，こうした対策 を施せば，長期間備蓄可能な材料である.

\section{4. 即効性のある応急復旧工法の効果}

\section{(1) 応急復旧の対象とした橋脚}

提案する応急復旧工法の効果を検証するために，柱基 部に損傷が生じた模型に対して提案工法による応急復旧 を行い，復旧された模型に対して振動台加震実験を行っ た. 以降，本文では損傷を生じさせる実験を損傷実験， 提案工法による復旧後の模型に対する実験を復旧実験と 呼ぶこととする.

復旧実験に用いた橋脚模型は 3 体であり，表-1，図-1, 図-2 に示したとおり断面の直径が $0.6 \mathrm{~m}$ の円形断面 RC 橋脚模型である. 模型は，昭和 55 年より前の設計基準 によって設計された橋脚を想定しており，帯鉄筋は重衫 


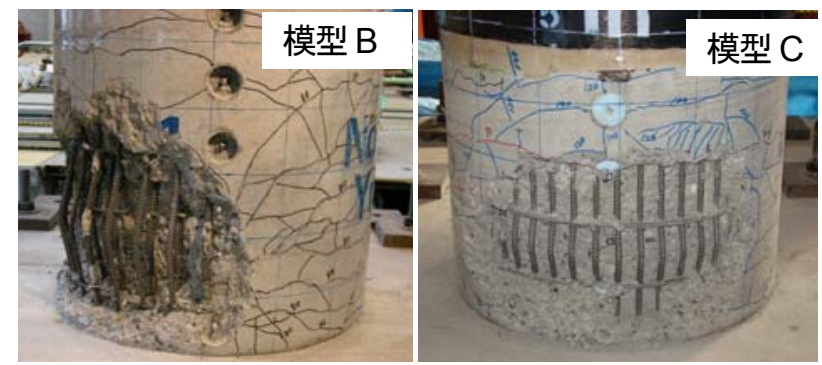

図-9 加震後の損傷状況（補修前の状況）

継手により定着している．断面の直径はいずれも $0.6 \mathrm{~m}$ である. 模型 $\mathrm{A}$ は，2 章に示した加震実験で損傷した模 型である.

模型 $\mathrm{B}$ の柱部の高さは $2 \mathrm{~m}$ である。軸方向鉄筋として $\mathrm{D} 10$ が合計 80 本（2.5 段配筋）配置されている．帯鉄筋 には直径 $3 \mathrm{~mm}$ の異形棒鋼（D3）が $100 \mathrm{~mm}$ 間隔で配筋 されている. ただし，柱部の上下端の外側の横拘束筋の み間隔が $50 \mathrm{~mm}$ 間隔となっている。带鉄筋は継ぎ手長 が $100 \mathrm{~mm}$ の重齐継ぎ手で定着されている．軸方向鉄筋 比は 2.02\%であり，帯鉄筋比は柱基部など帯鉄筋間隔が $50 \mathrm{~mm}$ の区間において 0.21\%である。実験日における柱 部のコンクリートの圧縮強度は $27.9 \mathrm{~N} / \mathrm{mm}^{2}$ であり，軸方 向鉄筋，帯鉄筋の降伏強度はそれぞれ $351 \mathrm{~N} / \mathrm{mm}^{2} ， 280$ $\mathrm{N} / \mathrm{mm}^{2}$ である。模型 $\mathrm{B}$ に対しては，基部で曲け破壊する タイプを想定して兵庫県南部地震の被害を再現するため の実験が行われている9 .

模型 C の柱部の高さは $2.175 \mathrm{~m}$ であり, 基部から高さ $0.9 \mathrm{~m}$ で内側の軸方向鉄筋が，高さ $1.5 \mathrm{~m}$ で外側の軸方向 鉄筋の半分がそれぞれ段落しされており，上部の段落し 部で曲げ損傷が生じるように設計されている．柱基部に は D10 が合計 96 本（2 段配筋）配置されている. 横拘 束筋としては D6 が $100 \mathrm{~mm}$ 間隔て配置されている. 帯 鉄筋は重衫継ぎ手により定着しており，重㸚継ぎ手長は 170mm である. 以上より, 軸方向鉄筋比は柱基部, 下 部段落し部，上部段落し部でそれぞれ $2.42 \% ， 1.21 \%$, 0.61\%となる．また，帯鉄筋比は柱基部，下部段落し部， 上部段落し部でそれぞれ $0.49 \% ， 0.24 \% ， 0.24 \%$ となる. 材料試験に基づくコンクリートの圧縮強度は $32 \mathrm{~N} / \mathrm{mm}^{2}$, 軸方向鉄筋，帯鉄筋の降伏強度はそれぞれ $394 \mathrm{~N} / \mathrm{mm}^{2}$, $327 \mathrm{~N} / \mathrm{mm}^{2}$ である. 模型 C は段落し部に対する応急復旧 効果実験の後に段落し部を修復し, かつ炭素繊維シート を縦方向に巻立てることによって曲げ補強し，再実験に より柱基部で曲げ損傷を生じさせた模型である．段落し 部に対する応急復旧については速乾性材料を用いた CFS 巻立て工法が用いられている. 本実験の詳細については 文献 10)を参照されたい，なお，段落し部の曲げ耐力補 強のための CFS は基部からの高さが $0.5 \mathrm{~m} \sim 2 \mathrm{~m}$ の範囲 に貼付した. CFS の定着長としては，上部段落し部およ び下部段落し部からそれぞれ $1 \mathrm{~m}$ が必要となるが，上部
については横はり部があるため, 下部については柱基部 に曲げ損傷を生じさせるために，上下部ともに必要とさ れる定着長より短い定着長とした，ただし，これによっ て定着部に CFS の剥離等が生じなかったことは実験に おいて確認している.

模型 $\mathrm{A}$ の実験条件，加震条件は 2 章に示したとおり である。模型 B，模型 Cの実験セットアップとしては, 図-3(b)に示寸ように桁とそれに上載した鋼製ブロックに よるおもりを実験模型上と両端の端部橋脚上の支承によ って支持する構造が用いられている. ここで, 橋軸方向, 橋軸直角方向はそれぞれ $\mathrm{Y}$ 方向, $\mathrm{X}$ 方向と定義されて いる. 支承条件は, 実験模型上では橋軸 $(\mathrm{Y})$ ・橋軸直 角 $(\mathrm{X})$ 方向ともに固定，回転は自由，端部橋脚上では 橋軸（Y）方向は自由，橋軸直角（X）方向は固定，回 転は自由である. セットアップの際の桁とおもりの安定 性に配慮して, 実験模型上の固定支承の両脇に橋軸直角 方向に対する転倒方止のための支承が設置されている. 以上の条件より，橋軸方向には橋脚天端が慣性力作用位 置になるが，橋軸直角方向には桁と上部ブロックの重心 位置が慣性力の作用位置となる．また，慣性質量は橋軸 方向には桁と上部ブロックの全質量に相当するが，橋軸 直角方向には端部支点も慣性質量を分担するため, 模型 橋脚に作用する慣性質量は全質量の 70\%となる.

入力地震動としては, 模型 $\mathrm{B}$, 模型 $\mathrm{C}$ に対しても模型 $\mathrm{A}$ と同様に JR 鷹取駅の記録が用いられている. 模型 $\mathrm{B}$ に対しては, 水平 2 方向十上下方向の 3 方向加震とし, 振幅を 10\%とした弾性レベル加震と $80 \%$ とした非線形レ ベル加震が行われている. 時間軸は相似則に従い $60 \%$ に 圧縮されている.

模型 Cに対しては, 水平 2 方向十上下方向の 3 方向加 震とし, 振幅を $10 \%$ とした弾性レベルの加震の後, 加震 振幅の倍率を $50 \% ， 80 \% ， 100 \%$ と増加させて，目標とす る損傷を生じさせることとした．ただし，80\%加震にお いて, 橋軸直角方向の慣性力作用位置が高いことによっ て柱頂部付近に曲げ損傷が生じたため, 柱基部に損傷を 確実に生じさせるためにこれ以降は橋軸方向水平 1 方向 十上下方向の 2 方向加震として, 振幅倍率を $80 \%$, 100\%，120\%とした加震を行った．時間軸は相似則によ り，50\%に圧縮した。

以上のように，損傷実験の目的が異なるために，3体 の配筋，セットアップ，加震条件はそれぞれ異なるが，

図-5 (3), 図-9 に示すように, 加震後の柱基部の曲げ破 壊による損傷は同程度であり, かぶりコンクリートの剥 落, 軸方向鉄筋のはらみ出しが生じた. なお, 軸方向鉄 筋の破断は生じていなかった.

復旧実験では，表-1 に示したように弾性レベル加震 として振幅を $10 \%$ とした加震を行った後, 2段階の非線 
表-4 補修の工程と作業に要した時間

(a) 速乾性材料を用いた CFS 巻立て工法

\begin{tabular}{|c|c|c|c|c|c|c|c|c|c|c|c|c|c|c|c|}
\hline 作業項目 & 所用時間 & $\mathrm{hr}$ & 1. & .0 & 2. & 0 & 3 & 0 & & 4.0 & & 5.0 & 6.0 & & 7.0 \\
\hline 表面コンクリートの除去 & $0: 20$ & $\leftrightarrow$ & & & & & & & & & & & & & \\
\hline 下地処理 & $0: 20$ & 4 & & & & & & & & & & & & & \\
\hline プライマー塗布 & $0: 20$ & & 4 & & & & & & & & & & & & \\
\hline プライマー養生 (硬化) & $1: 00$ & & & 4 & $\rightarrow$ & & & & & & & & & & \\
\hline 断面修復 & 1:00 & & & & S & 4 & $\rightarrow$ & & & & & & & & \\
\hline 断面修復材養生（硬化） & $1: 00$ & & & & & & & 4 & $\rightarrow$ & & & & & & \\
\hline 表面ケレン & $0: 20$ & & & & & & & & & $\mapsto$ & & & & & \\
\hline 不陸修正 & $0: 20$ & & & & & & & & & & 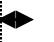 & & & & \\
\hline 不陸修正材養生（硬化） & $0: 50$ & & & & & & & & & & 4 & $\longrightarrow$ & & & \\
\hline 連続繊維シート巻立て（１層） & $0: 40$ & & & & & & & & & & & & $\mapsto$ & & \\
\hline 連続繊維シート養生（硬化） & $0: 50$ & & & & & & & & & & & & 4 & $\rightarrow$ & \\
\hline 合計 & $7: 00$ & & & & & & & & & & & & 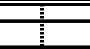 & $\rightarrow$ & \\
\hline
\end{tabular}

(b)機械式定着による繊維バンド巻立て工法

\begin{tabular}{|c|c|c|c|c|c|c|c|c|c|}
\hline 作業項目 & 所用時間 & $\mathrm{hr}$ & 1.0 & 2.0 & 3.0 & 4.0 & 5.0 & 6.0 & 7.0 \\
\hline 表面コンクリートの除去 & $0: 20$ & $\leftrightarrow$ & & & & & & & \\
\hline 下地処理 & $0: 40$ & 4 & $\rightarrow$ & & & & & & \\
\hline プライマー塗布 & $0: 20$ & & $\rightarrow$ & & & & & & \\
\hline プライマー養生 (硬化) & $1: 00$ & & & $\rightarrow$ & & & & & \\
\hline 断面修復 & $1: 00$ & & & & $\rightarrow$ & & & & \\
\hline 断面修復材養生（硬化） & $1: 00$ & & & & 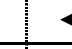 & $\rightarrow$ & & & \\
\hline ベルトの巻立て & $1: 10$ & & & & & 4 & $\longrightarrow$ & & \\
\hline 合計 & $5: 30$ & & & & & & $\rightarrow$ & & \\
\hline
\end{tabular}

表-5 応急復旧材料の特性

\begin{tabular}{|l|c|c|c|}
\hline & 模型 $\mathrm{A}$ & 模型B & 模型C \\
\hline \hline 断面修復材の弾性係数 $\left(\mathrm{kN} / \mathrm{mm}^{2}\right)$ & 19.5 & 8.6 & 25.1 \\
\hline 断面修復材の圧縮強度 $\left(\mathrm{N} / \mathrm{mm}^{2}\right)$ & 63.3 & 28.4 & 56.1 \\
\hline 繊維材の弾性係数 $\left(\mathrm{kN} / \mathrm{mm}^{2}\right)$ & 240.0 & 240.0 & 4.0 \\
\hline 繊維材の引張破断強度 $\left(\mathrm{N} / \mathrm{mm}^{2}\right)$ & 3950.0 & 3950.0 & 332.0 \\
\hline
\end{tabular}

注）断面修復材：MMA樹脂モルタル(模型A, B) 超速硬性無収縮モルタル(模型C)

繊維材 : 炭素繊維シート(模型A, B) ポリエステル繊維バンド(模型C)
形レベル加震を行った．非線形レベル加震では，損傷実 験における最大加震の振幅を本震とし，本震の約 $70 \%$ ベルの加震と $100 \%$ レ゙ルの加震を行った.

\section{(2) 提案工法による応急復旧}

本研究では，速乾性材料を用いたCFS巻立て工法を模 型 $\mathrm{A}$ ，模型Bに，機械式定着による繊維バンド巻立て工 法を模型Cに適用することとした. CFS巻き立て工法に ついては，巻立て層数の影響を調べるために，模型A， 模型Bに対してそれぞれ1層巻き，2層巻きとした。

いずれの工法を用いる場合にも，修復は損傷実験の翌 日に行った。ひび割れに樹脂注入等は行わなかった。ま た，提案工法による応急復旧の効果を評価しやすくする ために，実験では断面のサイズは増加させなかった。た だし，実橋脚では，はらみだした鉄筋の変形を修正する 等の作業が容易ではないと考えられるため, 断面サイズ を増加させる方が復旧をより早期に完了できる場合もあ ると考えられる。 なお，その場合にも，建築限界および
本復旧への影響等について，別途検討が必要である.

砕けたコンクリートは除去し，はらみ出した軸方向鉄 筋は整形しないことを基本としたが，模型Bでは，損傷 実験によるはらみ出し量が大きく, そのままでは断面サ イズが増加するため, ハンマーにより変形を修正して断 面の内側におさまるようにした．修復部の带鉄筋につい ては，CFS巻立て工法の場合は除去したが，機械式定着 工法の場合は相対的にせん断補強効果が小さいと考えら れたため，帯鉄筋をそのまま再配置した。その後の詳細 の工程は，3章に示した工程に従った. なお，繊維バン ドを定着する際には，ベルト締め機を用いて人力で行っ た. ベルトの緊張力は $1.2 \mathrm{kN}$ 程度である.

各工程の所要時間は表-4に示すとおりである.ここで は，CFS巻立て工法については1層巻きの結果を示して いる，復旧に要した時間は7時間であった，模型Bに対 する2層巻きの場合は，コアコンクリートの損傷が比較 的大きかったために断面修復に2時間を要し，2層目の巻 立てにも時間を要したので，全体としては8時間を要 


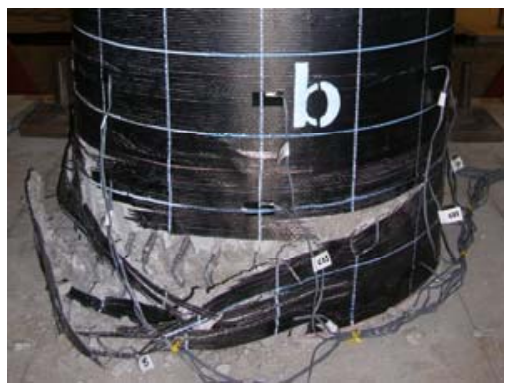

(a)模型 A（CFS1 層巻き）

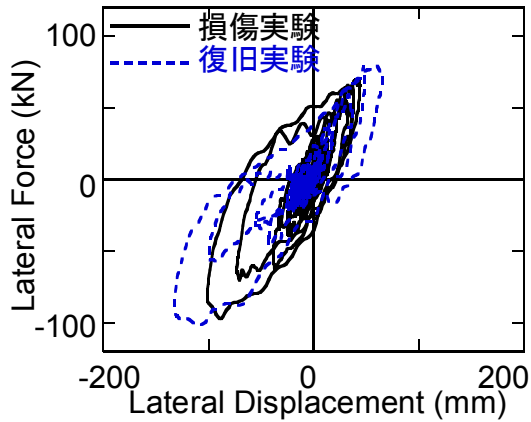

(a) 模型 A（CFS1 層巻き）

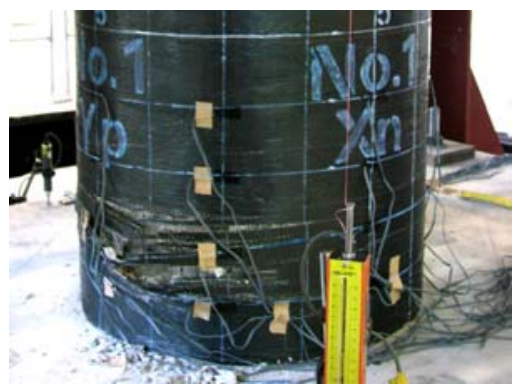

(b) 模型 B (CFS2 層巻き)

図-10 復旧実験後の損傷状況

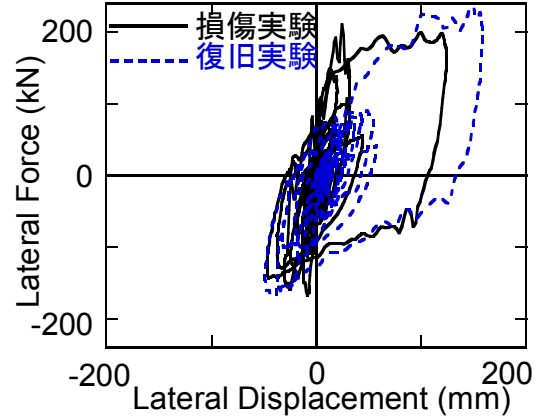

(b) 模型 B (CFS2 層巻き)

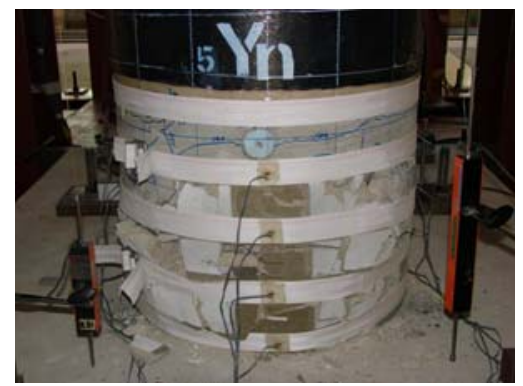

(c)模型 C（繊維バンド巻立て）

図-11 本震と同強度の余震が生じた場合の水平力〜水平変位の履歴（橋軸（Y）方向）

した．機械式定着工法による復旧の場合には，さらに短 い5時間半程度で完了した。 なお，復旧作業の中では， 断面修復作業にしめる時間が比較的大きかった。復旧作 業に要する時間を短縮するためには断面修復をいかに短 時間で完了するかがポイントであり，その点においても 断面修復に用いるモルタル材が施工性に優れることが重 要である.

表-5に応急復旧材料の特性を示す. MMA樹脂モルタ ルの材料特性は直径50 mm, 高さ100 mmのシリンダーの 圧縮試験から求めたが，模型Aと模型Bの材料試験結果 に大きな差が生じた.これは，上述のように施工性がよ くなく，品質管理が難しいことが一因と考えられる. CFS巻立て工法では，CFSは周方向のみの補強とするこ ととし，目付量 $200 \mathrm{~g} / \mathrm{m}^{2}$ （厚さ0.111 mm）のシートを用 いた. シートの引張破断強度は3950 N/mm²，弾性係数は $240 \mathrm{kN} / \mathrm{mm}^{2}$ である. CFSの巻立て数の影響を調べるため に，模型A，Bに対してそれぞれ1層巻き，2層巻きとし ており, CFSの体積比 $\rho_{C F}$ はそれぞれ0.074\%，0.148\%と なる.

機械式定着工法には，容易に入手可能な荷締め用ロー プとして用いられるポリエステル繊維バンドを用いるこ ととした。 なお， RC柱に対する接着工法による耐震補 強については，ポリエステル䋊維バンドによる工法が実 用化されている ${ }^{11) 13)}$ ，本実験で用いたポリエステル繊維 バンドは, 幅45 mm, 厚さ1.2 mm, 破断荷重 (公称值) が19 kN（2000 kg）のバンドである.引張試験によれば, ひずみゲージの計測に基づくバンドの弾性係数は4
$\mathrm{kN} / \mathrm{mm}^{2}$ である。引張破断強度は17.9 kNであり，これを 引張破断強度を応力として表すと $332 \mathrm{~N} / \mathrm{mm}^{2}$ である。ポ リエステル繊維バンドによる補強量は，炭素繊維シート 0.5層巻きに相当する程度とし， 45 mm幅のバンドを 100 $\mathrm{mm}$ 間隔で設置した。ここで, 繊維バンドの引張強度と しては破断強度を仮定した。

\section{(3) 提案工法の効果}

復旧実験後の最終損傷状況を図-10 に示す。図-11 に は各模型の最大強度の加震の際の水平力〜水平変位の履 歴を示す.ここでは，同じ地震動強度を入力させた場合 の損傷実験と復旧実験の履歴を比較している.

速乾性材料による CFS 巻立て工法の場合には，その 巻立て層数に関わらず本震の $70 \%$ 強度の余震を想定した 加震によってシートに軽微な破断が生じた．本震と同強 度の加震では図-10 に示すように CFS が破断し, 断面修 復材が圧壊, 剥落した。

一方，繊維バンドの機械式定着工法の場合には本震の 70\%強度の余震により断面修復材にひび割れが生じ, 繊 維バンドのひずみが最大で 0.01 に達し，バンドがわず かにはらみだした。本震と同強度の加震では断面修復材 の損傷は大きくなったが，バンドの伸び性能が高く，破 断しなかったため, 断面修復材は剥落しなかった.

ホワイトノイズ試験から推定した橋脚模型の固有周期 は損傷によって1.5〜2.6倍に増大するが，これを上記の 工法により修復すると剛性が多少回復するため, 固有周 期は健全な状態の1.3〜1.7倍となる. ただし, 補修後に 
表-6 要求性能の観点から見た提案工法の特徵

\begin{tabular}{|c|c|c|c|}
\hline 要求性能 & & 速乾性材料CFS巻立て & 機械式定着繊維バンド巻立て \\
\hline $\begin{array}{c}\text { a)-1 耐震性能の確保（せん断補強 } \\
\text { • 脆性的な破壊の防止） }\end{array}$ & & $\begin{array}{l}\text { シートを接着するため } \\
\text { 効果大 }\end{array}$ & 今後, 検討が必要 \\
\hline $\begin{array}{c}\text { a)-2 耐震性能の確保 } \\
\text { (変形性能) }\end{array}$ & $\triangle$ & $\begin{array}{l}\text { シートの破断のため } \\
\text { 大きくは期待できない }\end{array}$ & $\begin{array}{l}\text { (○) 高い伸び性能により } \\
\text { 効果大 }\end{array}$ \\
\hline $\begin{array}{l}\text { b) 施工管理が容易 } \\
\text { (施工性がよい) }\end{array}$ & & $\begin{array}{l}\text { 樹脂モルタルは粘性が高く } \\
\text { 充填性が悪い }\end{array}$ & \begin{tabular}{|cc} 
セメント系モルタルを \\
セ使用のため, 施エ性はよい
\end{tabular} \\
\hline c) 1日程度で復旧を完了 & 0 & 7時間程度（実験模型） & (0) 5.5時間程度（実験模型） \\
\hline d) 重機を要しない & $\mathrm{O}$ & シートは軽量 & ○ バンドは軽量 \\
\hline e) 長期の備蓄可能 & & $\begin{array}{l}\text { 樹脂系材料は品質保証 } \\
\text { 期間が } 6 \text { ヶ月程度 }\end{array}$ & $\begin{array}{c}\text { （材料によっては, } \\
\text { 紫外線対策等が必要） }\end{array}$ \\
\hline
\end{tabular}

もその岡性は損傷前の健全な状態の50\%に満たない．図 -11によれば，いずれの工法の場合にも，大きな塑性変 形が生じた段階（例えば，水平変位が100 mm程度の段 階）では，損傷実験と復旧実験における水平力は同程度 であるため，曲げ耐力としては健全な状態と同程度の耐 力が確保されると言える，応答変位としては，損傷を生 じさせた実験よりも30\%程度大きくなるケースもあるが, 復旧された橋脚はいずれも安定した地震応答を示してお り，こうした応急復旧により損傷前とほぼ同程度の耐震 性能を確保できたと考えられる.

\section{(4) 要求性能の観点からみた提案工法の評価}

3. (1)に示した要求性能の観点から本研究における実 験結果をふまえて，2つの提案工法を評価した。この結 果を表-6に示す。

短期的な而震性能の確保の観点では，せん断損傷を防 止し, 耐力を確保寸る観点ではCFS巻立て工法の方が優 れていると考えられるが，機械式定着工法による場合に も一定のせん断補強効果が期待できると考えられるため, 機械式定着工法による場合の必要補強量等を検討するた めの実験が必要である. 変形性能を確保する観点では, CFSは本震相当の加震によって生じたレベルの応答変位 が生じると破断したため，機械式定着工法の方が優れて いる.

施工管理による品質確保の観点からは，樹脂系モルタ ルを用いない機械式定着工法の方が優れている．復旧時 間に関しては，機械式定着工法の方が短い，重機を用い ないという観点では，いずれの工法も同じである．長期 間の備蓄に関しては, 樹脂系の材料の品質保証期間が短 いため，樹脂系の材料を用いない機械式定着工法の方が よい.

本研究で特に着目している，損傷の発見から1日以内 で応急復旧を完了するという観点からは特にc), e)が重 要であり, これらに関しては, 緎維バンドの機械式定着 工法の方が優れており，実用化に適していると考えられ る.

\section{5. 結論}

本研究では柱基部で曲げ破壊するRC橋脚を対象とし て，被災後の余震の影響を調べるとともに，即効性のあ る応急復旧工法を提案し，その効果を検証するための振 動台加震実験を行った. 復旧工法としては, 速乾性材料 による炭素繊維シート巻立て工法と機械式定着による繊 維バンド巻立て工法を提案した．以下に本研究で得られ た結論を示す。

1) 本震の後に余震により本震と同強度の地震力が作用す ると, 応答変位は増加したり, 損傷が進展する場合もあ るが，柱基部で曲け破壊するタイプの橋脚では，軸方向 鉄筋が破断する前であれば，本震規模の余震によって橋 脚の安定性が失われるような損傷の進展は生じなかった。 2) 応急復旧工法に求められる要求性能を整理した. 要求 性能は 5つあり, それらは, 短期的な耐震性能の確保, 品質管理が容易であること，1日程度で復旧作業を完了 すること，重機等による施工を必要としないこと，資材 が長期備蓄可能であることとした. 実験結果に基づき， 提案する工法の評価を行い, 機械式定着による繊維バン ドによる応急復旧工法が実用化には適していることを示 した.

3) 提案する工法により1日以内でのRC橋脚の応急復旧を 可能であることを実験模型に対する施工から示した.

4) 速乾性材料によるCFS巻立て工法により修復された橋 脚模型では, 本震の70\%強度の余震を想定した加震によ ってシートに軽微な破断が生じ，本震と同程度の加震で はCFSが破断し，断面修復材が圧壊，剥落した.

5) 機械式定着による繊維バンド巻立て工法により修復さ れた橋脚模型では, 本震と同強度の加震においても, バ ンドの高い伸び性能のために破断せず，断面修復材の剥 落もなかった。

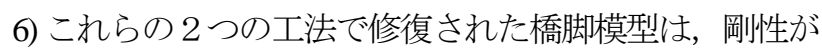
健全な状態に比べて $50 \%$ 以上低下寸るが，曲げ而扵は健 全な状態と同程度が確保される，応答変位としては大き くなる場合もあるが，地震応答性状は安定しており，提 案工法により損傷前とほぼ同程度の耐震性能を確保でき 
る.

\section{参考文献}

1)（社）日本道路協会 : 道路震災対策便覧（震災復旧編）， 2007.

2) 国土交通省国土技術政策総合研究所，独立行政法人土木研 究所, 独立行政法人建築研究所 : 平成 16 年（2004 年）新潟 県中越地震被害に係わる現地調査概要, 2005.

3) Yarandi, M. and Saatcioglu, M.: Rapid Seismic Repair of Shear Damaged Concrete Bridge Columns by Transverse Prestressing, Proc. 14th World Conference of Earthquake Engineering, CD-ROM 12-01-0256, Beijing, China, 2008.

4) 三田村浩, 安達優, 石川博之 : アラミドロープを用いた耐 震補強に関する実験的研究，寒地土木研究所月報 No. 656, pp. 26-35, 2008.

5) 堺淳一，小林寛，運上茂樹 : 鉄筇コンクリート橋脚に対する 地震時被荻度判定手法の開発，土木技術資料 Vol.51 No.2, pp. 32-35, 2009.

6) Nakamura, Y:: Waveform and its analysis of the 1995 Hyogo-ken Nanbu earthquake, JR Earthquake Information No. 23c, Railway Technical Research Institute, Japan, 1995.

7) Krawinkler, H. and Moncarz, P. D.: Similitude requirements for dynamic models, Dynamic Modeling of Concrete Structures SP 73-1, ACI, pp. 1-22, Detroit, Michigan, 1982.

8) 土木用 MMA 樹脂工法研究会 : <http://www.mma.or.jp/>

9) 堺淳一, 運上茂樹, 右近大道 : 兵庫県南部地震における RC 橋脚の被災再現のための振動台実験，地震工学論文集，土 木学会, Vol.29, pp.934-943, 2007.

10) 堺淳一，運上茂樹 : 軸方向鉄筋段落し部で曲げ破壊する RC 橋脚模型に対する振動台加震実験, 第 64 回土木学会年次学 術講演会, CD-ROMI-015, 2009.

11）田村玲, 田才晃, 壁谷澤寿海, 五十嵐俊一 : ポリエステル 製繊維シートによりせん断補強された RC 柱の構造性能，コ ンクリート工学年次論文集，Vo.25，No.2，pp.1507-1512,2003.

12) 稲熊弘，関雅樹 : 鉄道高架橋柱のポリエステル䋊維巻き而讨 震補強に関する実験的研究, 構造工学論文集, Vol.50A, pp.515-526, 2004.

13) 岩田秀治, 関雅樹 : 想定地震を考慮した鉄道高架橋柱の省 力化を図った耐震補強，第 9 回地震時保有耐力法に基づく橋 梁等構造の耐震設計に関するシンポジウム講演論文集, pp.77-84, 2006.

（原稿受理2009年6月28日）

\section{DEVELOPMENT OF RAPID REPAIR METHOD FOR REINFORCED CONCRETE BRIDGE COLUMN DAMAGED IN FLEXURE AT BOTTOM OF COLUMN DUE TO EARTHQUAKE}

\section{Junichi SAKAI and Shigeki UNJOH}

To ensure the structural safety against aftershocks and serviceability of bridges after an extreme earthquake, two rapid repair methods for a reinforced concrete bridge column are proposed. One method is based on carbon fiber sheet jacketing using quick-drying materials, and the other uses mechanical anchors for fiber band jacketing. Reinforced concrete bridge columns that suffered flexural damage at the bottom of the columns due to strong ground shaking were repaired by the proposed methods and a series of shake table tests was conducted to evaluate the effectiveness of the methods. The repair works were completed within 7 hours and 5.5 hours for the methods of quick-drying materials and mechanical anchors, respectively. The tests revealed that both the proposed methods can restore the seismic performance of reinforced concrete columns. Stable response and hysteresis of the repaired columns were observed during the shake table tests although the initial stiffness decreased by $50 \%$ due to seismic damage. 